\title{
A study of the mortality of workers in an asbestos factory
}

\author{
M. L. NEWHOUSE \\ London School of Hygiene and Tropical Medicine, TUC Centenary Institute of \\ Occupational Health
}

\begin{abstract}
Newhouse, M. L. (1969). Brit. J. industr. Med., 26, 294-301. A study of the mortality of workers in an asbestos factory. A cohort study of over 4,500 male workers employed at an asbestos factory making both textiles and insulation materials is described. The main analysis is of the mortality of workers employed between April 1, 1933, the date of the implementation of the Asbestos Regulations, and May 1, 1964. The analysis was made in relation to job, length of exposure, and length of follow-up after first exposure. There was no significant difference between the number of deaths occurring in the factory population and the national figures, until an interval of 16 years or longer had elapsed from first exposure in the factory. There were 1,160 men who fulfilled this criterion. In this group there was no excess mortality among those who worked in jobs where exposure was low or moderate, but among those with jobs which entailed heavy exposure there was a significant excess of deaths from cancer of the lung and pleura, and cancer of other sites, in men with a total period of employment in the factory of less than two years, as well as with those who worked for longer. Excess mortality from respiratory disease was observed only among severely exposed workers with long service.
\end{abstract}

The commercial use of asbestos dates from the latter part of the 19th century. Power-driven machinery was being rapidly developed and there were increasing demands for this material which is able to preserve heat and resist high temperatures. Italy was exporting asbestos as early as 1870; the Canadian chrysotile mines were in production by 1878 . At the end of the century crocidolite asbestos from South Africa was on the market; in 1907 amosite was discovered in the Central Transvaal and commercial production began in 1916. In the United Kingdom, chrysotile was first used in making asbestos products in about 1880 , crocidolite in 1895 , and amosite soon after its production started in South Africa.

The occurrence of pulmonary fibrosis in asbestos workers was recognized in the 1920s, and the association between the dust and disease was confirmed by a survey of factory workers carried out by Merewether and Price (1930). Later there were reports of pulmonary malignancies associated with asbestosis (Lynch and Smith, 1935; Doll, 1955). Wagner, Sleggs, and Marchand (1960) described pleural and peritoneal mesotheliomata in those who had been in contact with crocidolite asbestos. By the time of the First International Congress on the Biological Hazards of Exposure to Asbestos (Biological Effects of Asbestos, 1965) the carcinogenic and fibrogenic properties of asbestos had been generally accepted.

However, the industry continues to expand and asbestos is a vital ingredient of an increasing number of products. More knowledge is required of the size of the health risk under the varying conditions of the industry. This paper examines the mortality of past male workers at an asbestos factory in relation to their particular jobs in the factory, length of employment, and the duration of follow-up since first exposure.

The factory started production in the East End of London in 1913; at first employing only about 20 workers, it gradually expanded; by the late 1920 s there were between 300 and 400 workers, and by the 1950s the pay roll had increased to between 600 and 700. Asbestos textiles and insulation material were 
the major products. In the early 1950 s the textile departments were moved to another factory. A later development was the employment of laggers, mates, and labourers on insulating contracts at sites anywhere in the country. This activity was developed on an increasing scale from 1950 onwards.

Amosite, crocidolite, and chrysotile asbestos were all used in production, but crocidolite was not used for making sectional pipe segments after 1945. Its use continued in other departments.

\section{Source of data}

The data in this study were taken from the factory's personnel records which date back to 1913 and include all who have worked for any time in the factory. The name, address, date of birth, the actual jobs held with the dates of first engagement and final termination of each employee including those currently employed up to May 1, 1964 were abstracted. No attempt was made to trace those employed for less than 30 days. The co-operation of the Ministry of Social Security and the Registrar General was obtained, and each past worker's particulars were sent first to the Records Branch of the Ministry of Social Security. This register was able to identify $75 \%$ of the male workers and state whether they were alive or dead at May 1, 1964. The records of those unsuccessfully traced at this Ministry were sent to the National Health Central Register, where $30 \%$ of the remainder were identified. Searches of the electoral roll and more local registers were also made, bringing the overall trace rate up to $89 \%$ (Newhouse and Williams, 1967). The Registrar General provided the causes of death when the place and date of death had been determined.

The implementation of the Asbestos Regulations on April 1, 1933, which required the provision of exhaust ventilation in many processes, caused very considerable changes in the factory. The workers were therefore divided into three groups (Table 1) according to their period of employment. They consisted of the 4,695 men who worked entirely in the post regulation period, of whom all but $5 \%$ were traced; the small group of 140 men who worked before and after April 1, 1933, of whom all but $9 \%$ were traced; and 438 who worked entirely before the regulations, of whom only $50 \%$ were accounted for.

Studies of the first two groups are described in this

TABLE 1

Number of Workers Traced, in ReLATION to Date of EnForcement of Asbestos REGULATIONS

\begin{tabular}{|c|c|c|c|c|}
\hline $\begin{array}{l}\text { Employment in } \\
\text { asbestos factory }\end{array}$ & $\begin{array}{c}\text { Traced } \\
\text { alive }\end{array}$ & $\begin{array}{l}\text { Traced } \\
\text { dead }\end{array}$ & Untraced & Total \\
\hline $\begin{array}{l}\text { After April 1, } 1933 \\
\text { only } \quad \ldots \quad \ldots \\
\text { Before and after } \\
\text { April 1, } 1933 \text {. } \\
\text { Before April 1, } 1933\end{array}$ & $\begin{array}{r}4,183 \\
71\end{array}$ & $\begin{array}{r}274 \\
57\end{array}$ & $\begin{array}{r}238 \quad(5 \%) \\
12 \quad(9 \%)\end{array}$ & $\begin{array}{r}4,695 \\
140\end{array}$ \\
\hline only $\quad \ldots$ & 116 & 105 & $217(50 \%)$ & 438 \\
\hline
\end{tabular}

paper; the follow-up of the third was judged to be too incomplete for inclusion.

\section{Classification of jobs}

The experience of those with an intimate knowledge of the factory over the past $\mathbf{3 0}$ years was relied on to grade the $\mathbf{5 0}$ or more different jobs in the factory according to the severity of exposure to asbestos dust. Six grades were adopted ranging from grade 1 , which included office workers with very low exposure, to grade 6, which included disintegrators, openers, and others with heavy exposure (Table 2). Jobs in departments making rubber jointings, asbestos building boards, and certain insulating materials were put into grades 1 and 2, as the proportion of asbestos used in these products was low, varying between $5 \%$ and $18 \%$. Maintenance workers and those with similar jobs were considered to be moderately exposed (grade 3). The laggers, mates, and their labourers were put in the fourth grade. They worked on a variety of contracts outside the factory and had intermittent and varying exposure, depending on the type of insulating material used and the conditions of the particular job. They are considered separately as not only was the possible period of follow-up shorter than for men in other jobs, but also because the laggers had not infrequently been employed in their trade before entering the service of this particular factory. None of the men in exposure grades 1 to 3 worked regularly in areas where the Asbestos Regulations of 1931 applied. The severely exposed were divided into grade 5 and grade 6 . Workers in grade 5 were chiefly makers of sectional insulating material of high asbestos content, sectional pipe covers, and insulation slabs. Men in grade 6 were openers, disintegrators, workers in textile and mattress sections, and those employed in disposal of dust and waste. The environment of all the men in jobs graded as 5 and 6 was controlled by the regulations. The men in grade 6 jobs, but not grade 5 , were required under a separate statute to have initial and periodic medical examinations.

\section{Method of estimation of the risk}

The main survey was of the post-regulation period, from April 1, 1933 to May 1, 1964. Men qualified to enter the survey by having been on the factory's pay roll for 30 consecutive days at any time during that period. They continued in the survey, irrespective of whether they remained on the pay roll, until May 1, 1964 or the date of death if earlier.

For the analysis it was desired to categorize men by the length of time they were employed in the factory and by the type of job they did.

It was necessary to categorize men only by their past experience at any point, never by the experience yet to come. It was decided, therefore, to split the survey into three separate studies, defined as shown in Table 3. It is important to realize that the time scale, of entering and leaving the studies, refers to each man individually, according to his own 'E-day' (when he entered employment at the factory). Thus at any given calendar date there would be a number of men in each study.

If a man died, he was removed at that point from whichever study he was in at the time, and did not enter any later study at all. Similarly, when the survey terminated on May 1,1964, all men then in the survey were 
TABLE 2

Jobs in the Factory Graded by Severity of Exposure to Asbestos Dust and Showing Type of Fibre used in Manufacture of the Product

\begin{tabular}{|c|c|c|}
\hline $\begin{array}{l}\quad \text { Grade } 1 \text { (very low) } \\
\text { Staff and office } \\
\text { Grounds, gardens, and gatemen } \\
\text { Canteen } \\
\text { Laboratory } \\
\text { Stores } \\
\text { Mfc. rubber jointing }{ }^{1} \text { BC } \\
\text { Mfc. asbestos building boards }{ }^{1} \text { AC } \\
\text { Mfc. brake linings }{ }^{2} \text { C }\end{array}$ & $\begin{array}{l}\quad \text { Grade } 2 \text { (Low) } \\
\text { Clothing stores } \\
\text { Works and buildings } \\
\text { Cleaners } \\
\text { Mfc. insulating material }{ }^{1} \mathrm{C}\end{array}$ & $\begin{array}{l}\quad \text { Grade } 3 \text { (Moderate) } \\
\text { Metal shop } \\
\text { Engineers } \\
\text { Electricians } \\
\text { Despatch and packing } \\
\text { Laundry }\end{array}$ \\
\hline $\begin{array}{l}\text { Grade } 4 \text { (Moderate-severe) } \\
\text { Laggers ABC } \\
\text { Mates ABC } \\
\text { Labourers ABC }\end{array}$ & 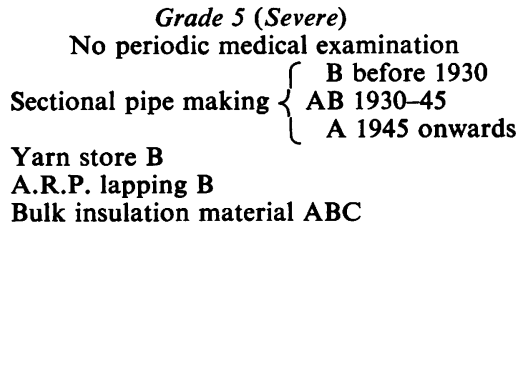 & 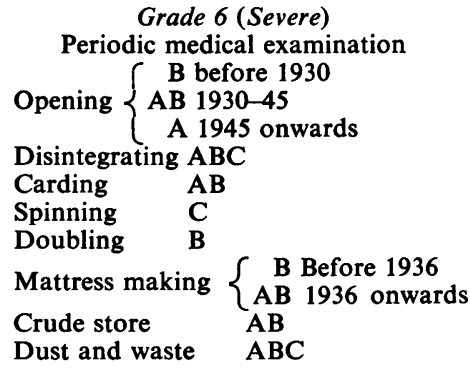 \\
\hline
\end{tabular}

${ }^{1}$ Asbestos content of product less than $20 \%$.

A $=$ Amosite.

$\mathbf{B}=$ Crocidolite

$\mathrm{C}=$ Chrysotile.

TABLE 3

Method of Allocating Workers to the Three SeParate Studies

\begin{tabular}{lll|l|l}
\hline Enter employment at factory & E-day & \\
Enter survey &. &. & S-day & E-day +30 days \\
Enter study 1 & $\ldots$ & $\because$ & & S-day +1 year \\
Leave study 1 & $\ldots$ & \} & & S-day +4 years \\
Enter study 2 & $\ldots$ & \{ & & S-day + 16 years \\
Leave study 2 & $\ldots$ & \{ \\
Enter study 3 &. & & & \\
\hline
\end{tabular}

treated as being removed from their respective studies.

For the analysis of each study the categorization was done by length of time on the payroll and by maximum job grade. For example, if a man started work as a disintegrator, a grade 6 job, he remained in grade 6 in all studies, even if he moved to a job in a lower grade, but if, as rarely happened, a worker started in a job with low exposure grading and later he moved into a higher exposure grade, he would be regraded in subsequent studies. If he remained on the pay roll for a period of months only he remained a short-service man in all three studies, but if he was employed in the factory for a number of years he would be regraded according to his length of time on the pay roll at the beginning of each study.

The workers who survived and who died in each subgroup or each study were listed by computer. The cause of death was taken from the death certificate and coded according to the Seventh Revision of the International Classification of Diseases (W.H.O., Geneva, 1957).
Death rates for England and Wales were taken from the Case Pearson tables (General Register Office, 1957; Case and Harley, 1958). These tables give age, specific death rates for cancers of various sites and for respiratory diseases for five-year age groups, for quinquennia from 1911, until 1960-65. The number of years contributed by each man in each subgroup for each five-year period was calculated. Multiplication of the sum of the man years by the relevant death rate in the Case Pearson tables gave the expected number of deaths (Doll, 1955). The computer programme for this purpose was written in Hill's (to be published) Man Year's Computer Language.

\section{Results}

There was little difference in the mortality experience of men in exposure grades 1,2 , and 3 and they have been grouped together. The severely exposed workers in grades 5 and 6 also had a similar mortality experience, and these have also been grouped together. In study 3 , however, there appeared to be a certain difference in the mortality experienced by the two severely exposed groups. The deaths from malignant disease (ICD 140-205) have been subdivided only into cancers of the lung and pleura (ICD 162, 163) and cancers of other sites. More detailed studies of the cancers are reported elsewhere (Newhouse and Wagner, 1969). The respiratory diseases were also grouped together and the figures for the expected number of deaths were taken from 
the Case Pearson table which gives death rates for all types of respiratory disease, including the pneumoconioses, but excluding upper respiratory disease, influenza, and cancer of the lung and pleura.

\section{Study 1}

The men were categorized by their working experience in the factory during their first year after entry to the survey. It included all who started work between April 1, 1933 and April 30, 1963, and concerned 3,268 men. The mortality experienced between the second and fifth years after entering the study is shown in Table 4. Among those with low to moderate exposure, there were 14 deaths, whereas $19 \cdot 2$ were expected, and among those with severe exposure 10 deaths were found, with 14.6 expected. There was no excess of deaths from either cancers of the lung and pleura or other cancers or from respiratory disease. At this stage the experience of the factory population appeared to be more favourable than that of the general population.

\section{TABLE 4}

Study 1: MoRtality BeginNing of 2ND to END OF 4TH YEAR ${ }^{1}$

UNDER 1 Year on Payroll $(3,268 \text { men observed })^{2}$

\begin{tabular}{|c|c|c|c|c|}
\hline \multirow{3}{*}{ Cause of death } & \multicolumn{4}{|c|}{ Exposure } \\
\hline & \multicolumn{2}{|c|}{ Low-moderate } & \multicolumn{2}{|c|}{ Severe } \\
\hline & Obs. & Exp. & Obs. & Exp \\
\hline $\begin{array}{lll}\text { All causes } \ldots & . & \ldots \\
\text { Cancer of lung and pleura .. } \\
\text { Other cancers } & \ldots & \ldots \\
\text { Respiratory diseases } & \text { ex- } \\
\text { cluding cancer } & . & \ldots \\
\text { Other diseases } & \ldots & \ldots\end{array}$ & $\begin{array}{r}14 \\
1 \\
1 \\
3 \\
9\end{array}$ & $\begin{array}{r}19 \cdot 2 \\
1 \cdot 1 \\
2 \cdot 6 \\
3 \cdot 5 \\
11 \cdot 9\end{array}$ & $\begin{array}{r}10 \\
0 \\
2 \\
\\
2 \\
6\end{array}$ & $\begin{array}{r}14 \cdot 6 \\
0 \cdot 7 \\
1 \cdot 7 \\
\\
3 \cdot 0 \\
9 \cdot 2\end{array}$ \\
\hline
\end{tabular}

${ }^{1}$ In these tables tests of significance were made by reference to the Poisson distribution and are entered where $P$ is less than 0.05 .

'Laggers' mates and their labourers are excluded from the populations whose mortality is described in Tables 4-9.

\section{Study 2}

In this study the men were categorized by their experience in the factory during the first five years in the survey, having entered it at any date between April 1, 1933 and April 30, 1959. There were more than 3,300 men in the study. Depending on the date of entry, the number of years of follow-up varied between 5 and 16 years. Tables 5 and 6 show the mortality of those with less than two years and for longer periods of employment in the factory; the deficiency in the observed number of deaths has tended to disappear. There are no significant findings, but the number of deaths from cancers of the lung
TABLE 5

Study 2: Mortality From BeginNing of 5TH TO END OF 16TH YEAR

UNDER 2 Years on PAYroll (1,677 men observed)

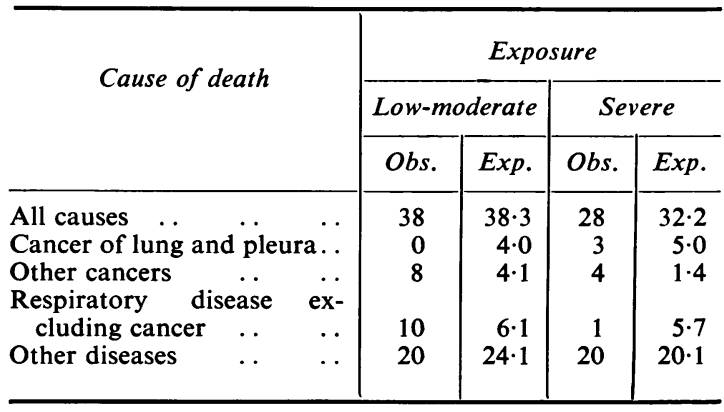

TABLE 6

Study 2: Mortality FROM BeginNing OF 5TH TO END OF 16TH YEAR

OVER 2 Years on Payroll (980 men observed)

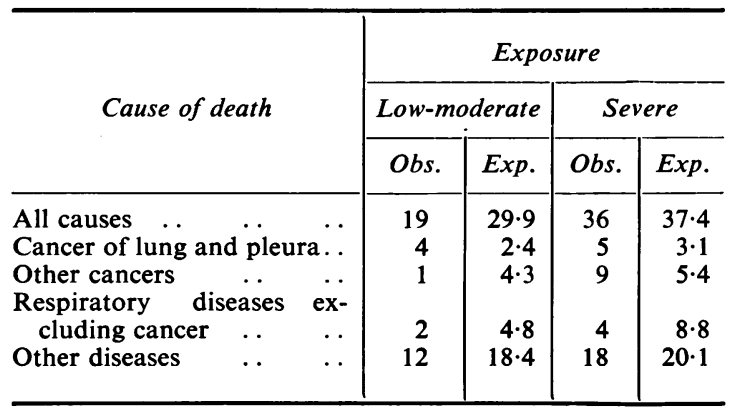

and pleura among those with longer exposures is higher than the expected figure.

\section{Study 3}

This study included only those who had been followed for at least 16 years since entering the factory. Their dates of entry to the survey fell between April 1, 1933 and April 30, 1948. There were 464 men with low to moderate exposure and 696 with severe exposure, comprising $\mathbf{3 7 5}$ in grade 5 exposure jobs and 321 in grade 6.

The group with low to moderate exposure showed no excess mortality either among those with less than two years, or among those with more than two years, employment in the factory (Tables 7 and 8).

Among the severely exposed group employed in the factory for less than two years there was a statistically significant mortality excess both from cancers of the lung and pleura and from cancers of other sites. Among those with more than two years employment in the factory, there was an excess 
TABLE 7

S IUdy 3: MORTALITY FROM BEgINNING OF 17TH TO END OF 31ST YEAR

Under 2 Years on Payroll (689 men observed)

\begin{tabular}{|c|c|c|c|c|}
\hline \multirow{3}{*}{ Cause of death } & \multicolumn{4}{|c|}{ Exposure } \\
\hline & \multicolumn{2}{|c|}{ Low-moderate } & \multicolumn{2}{|r|}{ Severe } \\
\hline & Obs. & Exp. & Obs. & Exp. \\
\hline $\begin{array}{l}\text { All causes.. } \\
\text { Cancer of lung and }\end{array}$ & 16 & $16 \cdot 8$ & 34 & $19 \cdot 1 \mathrm{P}<0.01$ \\
\hline $\begin{array}{cc}\text { pleura } \ldots & \ldots \\
\text { Other cancers } & \ldots\end{array}$ & $\begin{array}{l}2 \\
1\end{array}$ & $\begin{array}{l}1 \cdot 4 \\
2 \cdot 4\end{array}$ & $\begin{array}{l}8 \\
9\end{array}$ & $\begin{array}{l}1.6 \mathrm{P}<0.001 \\
2.7 \mathrm{P}<0.001\end{array}$ \\
\hline $\begin{array}{l}\text { Respiratory dis- } \\
\text { eases excluding }\end{array}$ & & & & \\
\hline $\begin{array}{cc}\text { cancer } \ldots & \ldots \\
\text { Other diseases } & \ldots\end{array}$ & $\begin{array}{r}1 \\
12\end{array}$ & $\begin{array}{r}2 \cdot 5 \\
10 \cdot 5\end{array}$ & $\begin{array}{r}2 \\
15\end{array}$ & $\begin{array}{r}2 \cdot 6 \\
12 \cdot 1\end{array}$ \\
\hline
\end{tabular}

TABLE 8

Study 3: Mortality From BeginNing of 17th TO END OF 31ST YeAR

OVer 2 Years on Payroll (471 men observed)

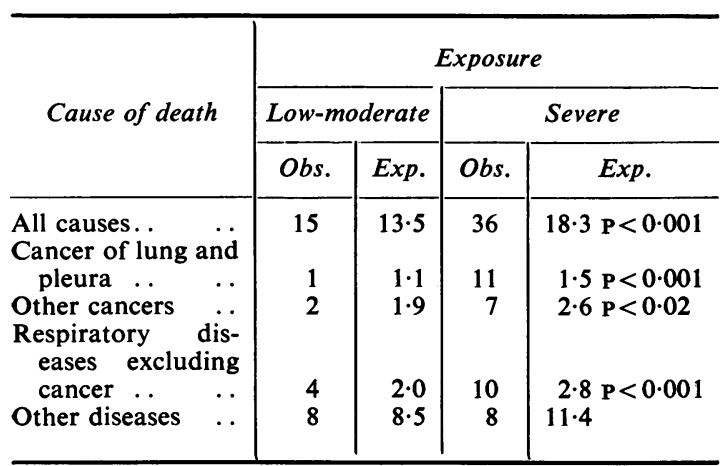

mortality from cancer of the lung and pleura, cancer of other sites, and from respiratory disease; four of the latter were certified as dying from asbestosis; neither among those with short or those with longer periods of employment was there any excess of deaths from causes other than cancer or respiratory disease

A more detailed analysis of the mortality of the severely exposed men in study 3 A significant excess of deaths from cancer of the lung and pleura and from cancer of other sites occurred in the short service men in the grade 5 exposure group (Table 9) but not in the grade 6 group. Among the former there wer six certified as having died of cancer of the lung and pleura, whereas 1.0 was expected $(P<0.001)$; in the grade 6 group the figures were two deaths observed to 0.6 expected, which is not statistically significant.
In the longer service group (Table 10) both the grade 5 and grade 6 categories showed a statistically significant excess of deaths from cancers of the lung and pleura. The deaths from respiratory disease, however, were concentrated among the men in the grade 5 category (nine observed to 1.8 expected $P<0.001)$. The grade 5 exposure group was larger than the grade 6 group, with 39 more men with short service and 13 more with long service, but the age structure of both groups appeared to be very similar, and there was no evidence that the length of followup varied in the two groups.

To determine more precisely the length of followup requir ed after first exposure before a significant excess of deaths from cancers and respiratory diseases could be demonstrated, both the observed and the expected number of deaths among the severely exposed were grouped into five-year periods. The first period was from the 17th to the 21st year, the second from the 22nd to the 26th year, and the third from the 26th to the 31st year. In the group who had been followed from 17 to 21 years, among men with less than two years' employment in the factory there was a statistically significant excess of deaths both from lung cancer and from other cancers; among those with longer service there was a significant excess of deaths from cancer of the lung and pleura and from respiratory disease, but not from cancers other than pulmonary cancers. After a follow-up period of more than 21 years there was a statistically significant excess of deaths from cancer of the lung and pleura in men with both long and short periods of employment, there was an excess of deaths from other cancers only among men with shorter periods of employment. There were no deaths observed in this group from respiratory disease.

TABLE 9

Study 3: Mortality OF WORKers in Grades 5 AND 6 EXPOSURE CATEGORIES Less than 2 Years on Pay Roll (429 men observed)

\begin{tabular}{|c|c|c|c|c|}
\hline \multirow{3}{*}{ Cause of death } & \multicolumn{4}{|c|}{ Exposure } \\
\hline & \multicolumn{2}{|r|}{$\begin{array}{l}\text { Severe } \\
\text { Grade } 5\end{array}$} & \multicolumn{2}{|c|}{$\begin{array}{l}\text { Severe } \\
\text { Grade } 6\end{array}$} \\
\hline & Obs. & Exp. & Obs. & Exp. \\
\hline $\begin{array}{l}\text { All causes . } \\
\text { Cancer of lung and }\end{array}$ & 23 & $11 \cdot 1 \mathrm{P}<0.001$ & 11 & $8 \cdot 0$ \\
\hline $\begin{array}{ccc}\text { pleura } & . & \end{array}$ & 6 & $1.0 \mathrm{P}<0.001$ & 2 & 0.6 \\
\hline $\begin{array}{l}\text { Other cancers } \\
\text { Respiratory diseases }\end{array}$ & 8 & $1.7 P<0.001$ & 1 & $1 \cdot 0$ \\
\hline $\begin{array}{l}\text { excluding cancer } \\
\text { Other diseases } \quad . .\end{array}$ & $\begin{array}{l}0 \\
9\end{array}$ & $\begin{array}{l}1.5 \\
6.9\end{array}$ & $\begin{array}{l}2 \\
6\end{array}$ & $\begin{array}{l}1 \cdot 1 \\
5 \cdot 2\end{array}$ \\
\hline
\end{tabular}


TABLE 10

Study 3: Mortality of Workers in Grades 5 and 6 Exposure Categories MORE THAN 2 Years on PAY Roll (241 men observed)

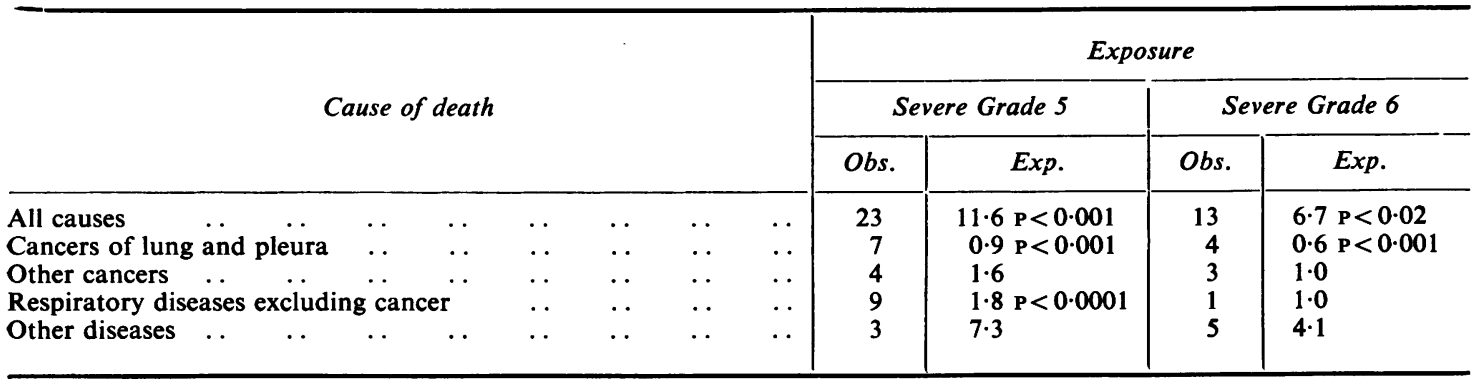

TABLE 11

Mortality OF Men Working both before AND AFter APRIL 1, 1933 OVER 2 Years on Pay Roll (140 men observed)

\begin{tabular}{|c|c|c|c|c|c|c|c|c|c|c|}
\hline & & & & & & \multicolumn{5}{|c|}{ Exposure } \\
\hline \multirow{2}{*}{\multicolumn{6}{|c|}{ Cause of death }} & \multicolumn{3}{|c|}{ Low-moderate } & \multicolumn{2}{|c|}{ Severe } \\
\hline & & & & & & Obs. & \multicolumn{2}{|r|}{ Exp. } & $\frac{\text { Obs. }}{28}$ & Exp. \\
\hline $\begin{array}{l}\text { All causes .. . .. } \\
\text { Cancers of lung and pleura } \\
\text { Other cancers } \\
\text { Respiratory diseases excludin } \\
\text { Other diseases } \quad . .\end{array}$ & $\begin{array}{l}\ldots \\
\ldots \\
\ldots \\
\text { ancer } \\
\ldots\end{array}$ & $\begin{array}{l}\ldots \\
\cdots \\
\cdots \\
\cdots \\
\ldots\end{array}$ & $\begin{array}{l}. \\
\cdots \\
\cdots \\
\cdots \\
\cdots\end{array}$ & $\begin{array}{l}. \\
\cdots \\
\cdots \\
\cdots \\
\ldots\end{array}$ & $\begin{array}{l}. \\
\cdots \\
\cdots \\
. \\
.\end{array}$ & $\begin{array}{r}24 \\
4 \\
4 \\
7 \\
9\end{array}$ & $\begin{array}{rr}15 \cdot 5 \\
1 \cdot 0 \\
2 \cdot 2 & \\
3 \cdot 2 & \\
9 \cdot 0 & \end{array}$ & $\begin{array}{l}0.03<P<0.05 \\
P<0.02 \\
P<0.05\end{array}$ & $\begin{array}{r}28 \\
3 \\
7 \\
15 \\
3\end{array}$ & $\begin{array}{rl}10.9 & P<0.001 \\
0.7 & P<0.05 \\
1.7 & P<0.001 \\
0.6 & P<0.001 \\
7.9 & \end{array}$ \\
\hline
\end{tabular}

The laggers' mates and labourers

This is a group of over 1,200 men in which only 60 were employed between 1933 and 1948: two deaths were observed, both from cardiovascular disease, whereas $2 \cdot 35$ were expected. There were 623 employed on insulating contracts who had been followed for 5 to 16 years. They contributed six deaths, three of which were due to carcinoma of the lung and pleura (three observed - 0.38 expected $P<0.001$ ). These three men had only been employed by the firm for short periods, but one was known to have worked as a lagger for the previous 25 years; the past experience of the other two is unknown. Over 1,000 of this group had been followed for from 2 to 5 years, about half of whom were first employed in this firm after 1960 . There is no excess mortality (five deaths observed $\mathbf{- 7 . 0 1}$ expected).

Workers first employed before April 1, 1933 and continuing after

A group of 140 men was identified who started work before the Asbestos Regulations were implemented and continued into the post-regulation period. Three of these workers joined the factory in 1914, five in 1919 , and a few each subsequent year until 1929; between 1931 and 1933 a further $61(43 \%)$ started work. The workers were grouped by their experience in their first four years after entering the factory, and the same grading of jobs was adopted as in the studies of the post-regulation period.

There were four deaths among the men with less than two years on the pay roll; 0.39 were expected $(P<0.001)$; one of these deaths was due to asbestosis. The mortality experience of those with more than two years service is shown in Table 11. There was a statistically significant excess of deaths from cancer of the lung and pleura both among those with jobs graded as having low to moderate exposure and among those with severe exposure. In both groups there was also an excess of deaths from respiratory diseases. Eleven of the severely exposed and three of those with lesser degrees of exposure were certified as dying from asbestosis.

In this study the length of follow-up of the group was at most 45 and at least 31 years; this is very much longer than in the studies previously mentioned, but conditions in the factory before the introduction of the asbestos regulations of 1931 cannot now be gauged. It seems probable that all workers, whatever their individual jobs, may have had considerable exposure to asbestos dust. 


\section{Discussion}

The adoption of the 'three study plan' of analysis enabled the experience of different groups of workers to be examined in terms of job and duration of employment and in relation to their dates of first employment in the factory.

If the worker held more than one job in the factory he was categorized by the job in the highest exposure grade. More than $70 \%$ held only one job and, among the remainder, including those with long service, the normal pattern of employment was to start in a job with a high exposure grading and subsequently to change to a job with less exposure. It is possible that some of the workers were categorized by jobs held for only a small proportion of their total service, but this can have occurred only infrequently. Some difficulties were experienced in grading fitters and maintenance men who may have had varying degrees of exposure in their work; men in these jobs were included in the moderately exposed group. In this report there is a marked contrast between the mortality of the group, who were graded as having low to moderate exposure, and the mortality of those who were graded as severely exposed. There is no suggestion of an adverse effect on the mortality of the former group.

Enterline and Kendrick (1967) have shown rising standardized mortality ratios for cancers and respiratory diseases in men employed in asbestos building-product plants, friction material plants, and asbestos textile plants; the highest SMRs occurred in the textile plants which were reported to be the dustiest. In this factory also the statistically significant excess of observed deaths occurred among workers from departments which were believed to be the most dusty.

This excess was only seen in study 3 after a followup period of not less than 16 years. In study 1 , where the mortality was observed from the beginning of the second to the fifth year, there were fewer deaths observed than were expected (Table 12). This is not an unusual finding at the beginning of an epidemiological study of an occupational group, as men with severe disabilities are not eligible for recruitment to the industry (Doll and Hill, 1954; Selikoff, Churg, and Hammond, 1964). Pre-employment medical examinations of this group may have helped to exclude unfit men. From the beginning of the postregulation period in 1933 the workers in grade 6 were subjected to a pre-employment medical examination, and after 1942, when an industrial medical officer was first employed, all workers in the factory were medically examined before starting work. In study 2 , where the follow-up period is extended to between five and 16 years, the deficiency in the observed number of deaths has tended to disappear.

In study 3 the excess of observed over expected deaths certified as due to cancer of lung and pleura, and cancer of other sites among men with severe but short exposures was notable (Table 12). Seventeen out of a total of 34 deaths were due to cancer, whereas 3.3 would have been expected (Table 7). The mortality of men with this type of experience has not been examined until recently. Doll(1955), Knox, Doll, and Hill (1965), and Knox, Holmes, Doll, and Hill (1968) observed only workers with 10 or more years' exposure; Mancuso and El Attar (1968), in their study of a 1938-39 cohort of asbestos workers, grouped them according to their length of employment in an asbestos factory. They used the group with less than two years' exposure as an internal control; the incidence of cancer deaths rises with increasing periods of employment, but among those with less than two years' employment the SMR for malignant diseases in certain groups is over 200.

None of the insulation workers studied by Selikoff

TABLE 12

Ratio of Observed to EXPECTED Deaths

\begin{tabular}{|c|c|c|c|c|c|c|c|}
\hline \multirow{2}{*}{$\begin{array}{c}\text { Follow-up } \\
\text { period } \\
\text { (years) }\end{array}$} & \multirow{2}{*}{$\begin{array}{l}\text { Period on } \\
\text { pay roll } \\
\text { (years) }\end{array}$} & \multicolumn{2}{|c|}{ All causes of death } & \multicolumn{2}{|c|}{ Cancer of lung and pleura } & \multicolumn{2}{|c|}{ Other cancers } \\
\hline & & $\begin{array}{c}\text { Low-moderate } \\
\text { exposure }\end{array}$ & $\begin{array}{c}\text { Severe } \\
\text { exposure }\end{array}$ & $\begin{array}{c}\text { Low-moderate } \\
\text { exposure }\end{array}$ & $\begin{array}{c}\text { Severe } \\
\text { exposure }\end{array}$ & $\begin{array}{c}\text { Low-moderate } \\
\text { exposure }\end{array}$ & $\begin{array}{c}\text { Severe } \\
\text { exposure }\end{array}$ \\
\hline $\begin{array}{c}2-4 \\
\text { (Study 1) }\end{array}$ & $<1$ & 0.7 & 0.6 & 0.9 & $(0: 0 \cdot 7)^{1}$ & 0.4 & $1 \cdot 8$ \\
\hline $\begin{array}{c}5-16 \\
\text { (Study 2) }\end{array}$ & $\begin{array}{l}<2 \\
>2\end{array}$ & $\begin{array}{l}1.0 \\
0.6\end{array}$ & $\begin{array}{l}0.9 \\
1.0\end{array}$ & $\begin{array}{c}(0: 4 \cdot 0)^{1} \\
1 \cdot 6\end{array}$ & $\begin{array}{l}0.6 \\
1.6\end{array}$ & $\begin{array}{l}2 \cdot 0 \\
0 \cdot 2\end{array}$ & $\begin{array}{l}2 \cdot 9 \\
1 \cdot 7\end{array}$ \\
\hline $\begin{array}{c}17-31 \\
\text { (Study 3) }\end{array}$ & $\begin{array}{l}<2 \\
>2\end{array}$ & $\begin{array}{l}1.0 \\
1.0\end{array}$ & $\begin{array}{l}1.8 \\
1.9\end{array}$ & $\begin{array}{l}1.4 \\
0.9\end{array}$ & $\begin{array}{l}5 \cdot 0 \\
7 \cdot 3\end{array}$ & $\begin{array}{l}0.4 \\
1 \cdot 1\end{array}$ & $\begin{array}{l}5 \cdot 3 \\
2 \cdot 7\end{array}$ \\
\hline
\end{tabular}

${ }^{1}$ No deaths observed in this category.

The expected number of deaths is entered. 
and Hammond (1968) died from carcinoma of the lung, mesothelial tumours or asbestosis before 20 years had elapsed since first exposure. Among the workers at the asbestos factory reported in the present paper a significant excess of observed deaths from cancer of the lung and pleura, other cancers, and from respiratory diseases was found in certain groups of workers after a follow-up period of between 17 and 21 years, suggesting that the latent period of asbestos related disease may be less than 20 years in these workers. Of the entire group of post-regulation workers studied, $1,160(25 \%)$ have a follow-up period of 16 years or longer. Selikoff, Hammond, and Churg (1968) have revealed that cigarette smoking has an adverse effect on the mortality of asbestos workers; nothing is known of the smoking habits of this group as no direct contact was made with any worker. In future studies it may be possible to learn the smoking habits of selected groups of workers. A study of the mortality after May 1, 1964 is planned. Workers first exposed at later dates will have been followed for a sufficient length of time for asbestos related diseases to contribute to the causes of death. It will be possible to contrast their mortality experience with those employed earlier and to estimate whether comparatively modern methods of asbestos manufacture are reflected in an improved mortality experience.

My thanks are due to Dr. W. J. Smither and the Cape Asbestos Company for their invaluable assistance and co-operation; Mr. I. D. Hill of the MRC Computer Unit for devising the 'three study' plan, for the computer analysis, and for assistance with the manuscript; and to Professor R. S. F. Schilling, Dr. J. C. Gilson, and Mr. P. D. Oldham for assistance and advice at every stage of the investigation.

This work was undertaken with the assistance of a grant from the Medical Research Council.

\section{References}

Biological Effects of Asbestos (1965). Ann. N.Y. Acad. Sci., 132, 1-766. Case, R. A. M., and Harley, J. L. (1958). Cancer Death Rates by Site, Age and Sex for 'Tuberculosis and Selected Respiratory Diseases, England and Wales, 1911-1955'. Chester Beatty Research Institute, London (with additional material to 1960-65).

Doll, R. (1955). Mortality from lung cancer in asbestos workers. Brit. J. industr. Med., 12, 81-86.

, and Hill, A. B. (1954). The mortality of doctors in relation to their smoking habits. Brit. med. J., 1, 1451-1455.

Enterline, P. E., and Kendrick, M. A. (1967). Asbestos-dust exposures at various levels and mortality. Arch. environm. Hith, 15, 181-186.

General Register Office. Studies on Medical and Population Subjects, No. 13. (1957). Cancer Statistics for England and Wales 1901-1955 by McKenzie, A., with additional material by Case, R. A. M., and Pearson, J. T.

Hill, I. D. Draft Man Years Computer Language Manual (To be published.)

Knox, J. F., Doll, R., and Hill, I. D. (1965). Cohort analysis of changes in incidence of bronchial carcinoma in a textile asbestos factory. Ann. N.Y. Acad. Sci., 132, 526-535.

_- Holmes, S., Doll, R., and Hill, I. D. (1968). Mortality from lung cancer and other causes among workers in an asbestos textile factory. Brit. J. industr. Med., 25, 293-303.

Lynch, K. M., and Smith, W. A. (1935). Pulmonary asbestosis, III: Carcinoma of lung in asbestos-silicosis. Amer. J. Cancer, 24, 56-64.

Mancuso, T. F., and El Attar, A. A. (1968). Carcinogenic Risk and Duration of Employment among Asbestos Workers. Proceedings of the 2nd International Conference on the Biological Effects of Asbestos (in press).

Merewether, E. R. A., and Price, C. W. (1930). Report on Effects of Asbestos Dust on the Lungs and Dust Supression in the Asbestos Industry. [Home Office] H.M.S.O., London.

Newhouse, M. L., and Wagner, J. C. (1969). Validation of death certificates in asbestos workers. Brit. J. industr. Med., 26, 302-307.

- and Williams, J. M. (1967). Techniques for tracing past employees on an example from an asbestos factory. Brit. J. prev. soc. Med., 21, 35-39.

Selikoff, I. J., Churg, J., and Hammond, E. C. (1964). Asbestos exposure and neoplasia. J. Amer. med. Ass., 188, 22-26.

-, and Hammond, E. C. (1968). Community effects of nonoccupational environmental asbestos exposure. Amer. J. publ. Hlth, 58, 1658-1666.

- _ - and Churg, J. (1968). Asbestos exposure, smoking, and neoplasia. J. Amer. med. Ass., 204, 106-112.

Wagner, J. C., Sleggs, C. A., and Marchand, P. (1960). Diffuse pleural mesothelioma and asbestos exposure in the North Western Cape Province. Brit. J. industr. Med., 17, 260-271.

World Health Organization Manual of the International Statistical Classification of Diseases, Injuries, and Causes of Death. 1957. W.H.O., Geneva.

Received for publication February 17, 1969. 